\title{
First record of Salacia tetracythara Lamouroux, 1816 (Hydrozoa, Sertulariidae) as an alien hydroid for the Atlantic Ocean
}

\author{
Luana Marina de Castro Mendonça ${ }^{1,2,4}$; Carmen Regina Parisotto Guimarães ${ }^{2,5}$; \\ Manuel María González-Duarte, ${ }^{3,6}$ \& Maria Angélica Haddad ${ }^{1,2,7}$
}

\footnotetext{
1 Universidade Federal do Paraná (UFPR), Setor de Ciências Biológicas, Departamento de Zoologia (DZO0), Laboratório de Estudos de Cnidaria e Comunidades Incrustantes (LABECCI), Programa de Pós-Graduação em Zoologia. Curitiba, PR, Brasil.

2 Universidade Federal de Sergipe (UFS), Centro de Ciências Biológicas e da Saúde (CCBS), Departamento de Biologia (DBI). São Cristóvão, SE, Brasil.

${ }^{3}$ Universidad de Cádiz, Facultad de Ciencias del Mar y Ambientales, Departamento de Biología. Puerto Real, Cádiz, España.

${ }^{4}$ ORCID: http://orcid.org/0000-0002-0302-4046. E-mail: luana.castro@ufpr.br (corresponding author)

${ }^{5}$ ORCID: http://orcid.org/0000-0003-1996-3512. E-mail: carmenparisotto@gmail.com

${ }^{6}$ ORCID: http://orcid.org/0000-0002-1243-8232. E-mail: manuel.duarte@uca.es

7 ORCID: http://orcid.org/0000-0003-0485-6116. E-mail:mahaddad@ufpr.br
}

\begin{abstract}
We present here the first record of Salacia tetracythara as an alien species for the Atlantic Ocean, specifically the coast of the state of Sergipe, northeast Brazil. The species was found attached to an artificial experimental plate installed in the rainy period (July-0ctober 2017), in an estuarine region of the Sergipe River near the Sergipe Harbour. Salacia tetracythara is characterized by a small triangular space below each hydrotheca and two types of microbasic mastigophore nematocysts that differ in shape, size, and location. The species was described from Australia and has been recorded only for tropical to temperate regions of the Indo-Pacific. Salacia tetracythara seems to be a recent introduction into the Atlantic 0 cean and, its introduction probably derived from ship transport between the Sergipe Harbour and regions of Oceania and/or Asia. Further investigation should be conducted to determine whether the species is established in the region and how far inside the estuary it has gone.
\end{abstract}

Key-Words. Sertulariidae; Bioinvasion; Hydroids; Alien species; Artificial substrates.

\section{INTRODUCTION}

Hydroids constitute the polypoid stage of hydrozoans and are common components of benthic communities around the world (Gili \& Hughes, 1995). They can colonize and develop on different types of substrates (González-Duarte et al., 2014) and have high dispersive potential. Pelagic dispersal is not only performed by the medusa and/ or planula stages of the life cycle, but also by the presence of tolerant or resistant stages (frustules) released from colonies, autotomy of hydranths, as well as rafting of colonies on floating structures (Boero, 2002; Haydar, 2012). As a result, these organisms are among the groups with the highest number of species transported and introduced by human actions (Haydar, 2012). Many hydroid species have been successfully transported as fouling organisms on ship hulls, in ballast water (pelagic stages), or associated with the commercial traffic of other marine species (Farrapeira et al., 2011).

Salacia tetracythara Lamouroux, 1816 is a distinctive species of Salacia characterized by a small triangular space below each hydrotheca. This character is pointed out by several authors in their descriptions of the species, such as Billard (1925, pl. VIII, figs. 27 and 28), who wrote that "the adcaulinary wall is continued below the bottom by a perisarcal lamina that curls outwards and delimits a triangular space, characteristic of the species", and Watson (2000, fig. 18A-F), who described the adcaulinary wall of the hydrothecae as "floor of hydrotheca incurved to accommodate a thin circular to ovoid adcauline fenestration". Other authors did not describe the space below each hydrotheca, but their figures illustrate this distinctive characteristic of S. tetracythara (e.g., Gibbons \& Ryland, 1989, fig. 31; Gravier-Bonnet, 2008, fig. 2; Preker \& Lawn, 2010, fig. 11; Schuchert, 2003, fig. 37; Song, 2016, fig. 54). Other characteristics of the species can be found in Bale (1884), Billard (1925), Watson (2000), and Gravier-Bonnet (2008). The latter author also presents the taxonomic history of S. tetracythara.

Salacia tetracythara was previously recorded in tropical to temperate regions of the Indian 
and Pacific Oceans (Lamouroux, 1816; Bale, 1884; Billard, 1925; Rees \& Vervoort, 1987; Gibbons \& Ryland, 1989; Watson, 2000; Schuchert, 2003; Gravier-Bonnet, 2008; Song, 2016). In October 2017, two colonies of S. tetracythara were found on an experimental artificial substrate deployed in an estuary of the state of Sergipe on the northeast coast of Brazil (southwestern Atlantic Ocean). The site is near the Inácio Barbosa Maritime Terminal (TMIB), which operates national and international traffic. Thus, this paper presents the first record of S. tetracythara as an alien species for the Atlantic Ocean.

\section{MATERIAL AND METHODS}

The Sergipe River (Fig. 1) starts in the Serra Negra hills between the states of Sergipe and Bahia (NE Brazil) and has an extension of $210 \mathrm{~km}$, passing through the semiarid region of Sergipe and draining into the sea at Aracaju city (Fig. 1A, C). The Sergipe River is wide and deep throughout most of its extension, with a maximum width of $1.1 \mathrm{~km}$ in Aracaju and a minimum width of $6 \mathrm{~m}$ in Riachuelo city (Alcântara et al., 1979).

The estuarine region of the Sergipe River is near the TMIB port complex, which was created 26 years ago (1994) and transports solid and liquid bulk, grains, and other products. The port also offers offshore operations, receiving ships in the past ten years from different countries of Asia, Europe, Africa, and the Americas as well as different oceans (Atlantic, Pacific, and Indian and the Adriatic, China, Mediterranean, and Black Seas) (ANTAQ, 2019). The nearby Aracaju Waterway Terminal operates domestic transport and receives smaller vessels. There are also several warehouses for fishing oper- ations, which is one of the main economic activities of the state.

A public pier located approximately $5 \mathrm{~km}$ from the mouth of the river ( $\left.10^{\circ} 55^{\prime} 30.1^{\prime \prime} \mathrm{S}, 37^{\circ} 02^{\prime} 35.4^{\prime \prime} \mathrm{W}\right)$ (Fig. 1B), where small to medium-sized tourist boats dock was choose to develop the experiment. The location is also near piers of the Navy and Yacht Club of Aracaju for private boats. From January to April 2017 (dry period) and July to October 2017 (rainy period), three experimental sets of plates were attached to the public pier. Each set consisted of three pairs of polyethylene plates $(12 \times 12 \mathrm{~cm})$ fixed to a rope. After a submersion time of three months per period, each pair was detached from the rope and placed in a plastic bag with water from the site and anesthetized using menthol. The bags were transported to the Bentos Costeiro Laboratory of the Federal University of Sergipe in a thermal box with ice. In the lab, the liquid in each bag was replaced by $98 \%$ ethanol for subsequent analysis. These plates were part of a larger project, intending to determine hydroid species colonizing artificial substrates in estuarine regions of the state of Sergipe.

After sorting the fouling community, two infertile colonies of Salacia tetracythara were found on two plates of the same experimental set deployed in the rainy period. The colonies were photographed and measured using optical and stereo microscopes (Leica M205C and DM5500B, equipped with a 7-MP camera). Images were imported to the Leica Application Suite v4.4 (Montage and Analysis packages). The specimens were deposited in the Coleção Zoológica do Laboratório de Bentos Costeiro of Universidade Federal de Sergipe (CZUFS CNI). The classification used in the present study follow Leclère et al. (2009) and Maronna et al. (2016).
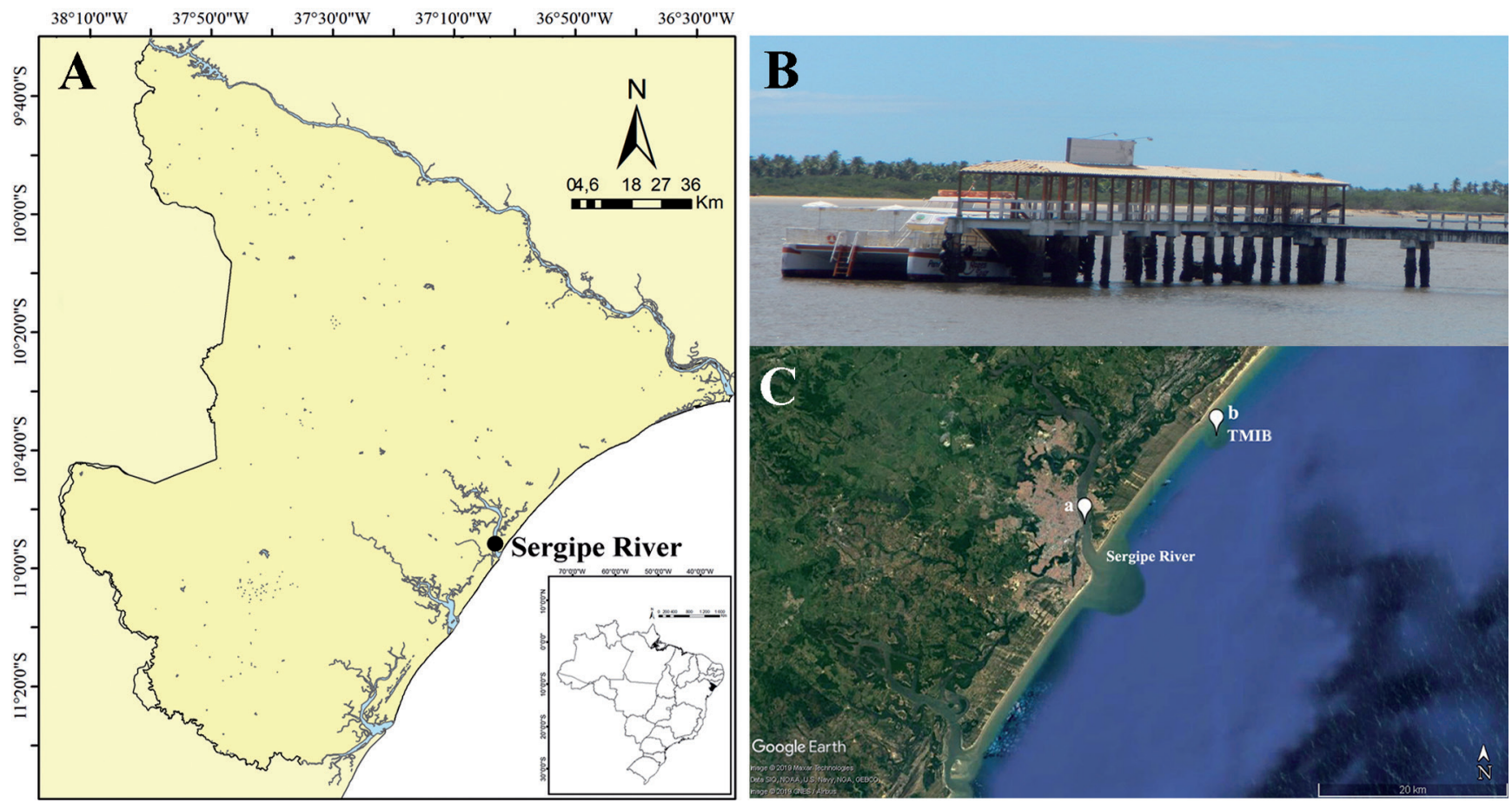

Figure 1. The location of experimental site. (A) Map of state of Sergipe showing Sergipe River and map of Brazil showing location of state of Sergipe; (B) pier where experimental sets were deployed; (C) Central portion of coast of Sergipe, showing pier location in Sergipe River (a) and TMIB (b) (Google Earth). 


\section{RESULTS}

\section{Class Hydrozoa Owen, 1843 \\ Subclass Hydroidolina Collins, 2000 \\ Superorder Leptothecata Cornelius, 1992 \\ Order Macrocolonia Leclère, Schuchert, Cruaud, Couloux \& Manuel, 2009 \\ Suborder Sertulariida Maronna, Miranda, Peña \\ Cantero, Barbeitos \& Marques, 2016 \\ Family Sertulariidae Lamouroux, 1812 \\ Genus Salacia Lamouroux, 1816 \\ Salacia tetracythara Lamouroux, 1816}

(Figs. 2A-F, 3A-C)

Synonyms available in Bale (1884); Billard (1925); Watson (2000).

Material examined: Two infertile colonies - CZUFS CNI-00065, $16.08 \mathrm{~mm}$, sampled on 10 October 2017, depth of $4 \mathrm{~m}$, rope 2, plates 1-2 (Fig. 2A); CZUFS CNI-00066, $7.13 \mathrm{~mm}$, sampled on 10 October 2017, depth of $4 \mathrm{~m}$, rope 2, plates 5-6 (Fig. 2B). The colonies described in this paper were found on an artificial substrate. At the collection site, which was $16.4 \mathrm{~km}$ (straight line) from the TMIB port area, the water column was $4 \mathrm{~m}$ deep, the mean temperature was $26.5^{\circ} \mathrm{C}, \mathrm{pH} 6.47$, salinity $24.3 \mathrm{ppm}$, and dissolved oxygen $48 \%$.

Description: Colonies erect, $7.13 \mathrm{~mm}$ (Fig. 2B) and $16.08 \mathrm{~mm}$ (Fig. 2A) high, bearing alternating hydrocladia. Stems unbranched arising from a thick, short hydrorhiza, perisarc thick, two lateral rows of unconnected hydrothecae in subopposite pairs, three between successive hydrocladia (one inferior, one axillary and one opposite). Hydrocladia straight and rigid, on a single plane, alternating, branched once in two hydrocladia. One colony bearing tendrils on all hydrocladia (average: $1.16 \pm 0.75 \mathrm{~mm}$ ). Hydrothecae in two lateral rows in opposite to subopposite pairs, members of the same pair not in contact, but successive hydrothecae of a row in contact or overlapping. Hydrothecae tubular, adnate for nearly their entire length, slightly curved distally, aperture rounded, vertical with delicate margin showing signs of renovation, operculum composed of one oval valve attached to abcauline side. No teeth observed on margin. Adcauline wall of hydrothecae extended below by a triangular to ovoid adcauline space below each hydrotheca (Fig. 2F). Only one type of nematocyst was found, probably large microbasic mastigophores (Fig. 3). Undischarged and discharged nematocysts were observed on stem and hydrothecae. The measurements are presented in Table 1.

Distribution: Australian tropical to temperate east and southeast coast (Lamouroux, 1816; Bale, 1884; Watson, 2000), Indian Ocean (Kei Islands, Gulf of Aden) (Rees \& Vervoort, 1987; Schuchert, 2003), tropical and subtropical regions of Indo-Pacific (Albany Passage, Comoros, and Mascarene archipelagos, Off Cumberland Island, Fiji, Murray Island) (Billard, 1925; Gibbons \& Ryland, 1989; Gravier-Bonnet, 2008), China Sea (Song, 2016).
Table 1. Mean and standard deviation of measurements of two colonies of Salacia tetracythara found in estuarine region of Sergipe River, northeast Brazil. Number of measurements taken in parentheses.

\begin{tabular}{|c|c|c|}
\hline & CZUFS CNI-00065 & CZUFS CNI-00066 \\
\hline Stem length (mm) & 16.083 & 7.134 \\
\hline Hydrorhiza length (mm) & 3.482 & 1.546 \\
\hline Hydrorhiza width (mm) & $0.232 \pm 0.017(3)$ & $0.172(2)$ \\
\hline Stem width $(\mathrm{mm})$ & $0.444 \pm 0.068(8)$ & $0.354 \pm 0.027(5)$ \\
\hline Stem width ${ }^{2}(\mathrm{~mm})$ & $0.222 \pm 0.025(10)$ & $0.155 \pm 0.057(11)$ \\
\hline Hydrocladia length (mm) & $3.715 \pm 1.965(6)$ & $3.228 \pm 0.986(7)$ \\
\hline Hydrocladia width ${ }^{1}(\mathrm{~mm})$ & $0.391 \pm 0.041(15)$ & $0.321 \pm 0.011(8)$ \\
\hline Hydrocladia width ${ }^{2}$ (mm) & $0.444 \pm 0.03(5)$ & $0.079 \pm 0.02(3)$ \\
\hline Hydrocladia tendrils length (mm) & do not have & $1.165 \pm 0.755(8)$ \\
\hline Hydrothecae length ${ }^{3}(\mu \mathrm{m})$ & $462 \pm 40(14)$ & $432 \pm 31(28)$ \\
\hline Hydrothecae width $(\mu \mathrm{m})$ & $110 \pm 12(12)$ & $105 \pm 10(11)$ \\
\hline Space bellow hydrothecae $(\mu \mathrm{m})$ & $80 \pm 9.3(5)$ & $89 \pm 21(14)$ \\
\hline Hydrothecae aperture $(\mu \mathrm{m})$ & * & $119 \pm 11(14)$ \\
\hline Hydrothecae operculum ( $\mu \mathrm{m})$ & * & $81(2)$ \\
\hline Nematocyst length undischarged ( $\mu \mathrm{m})$ & * & $17.7 \pm 2.46(14)$ \\
\hline Nematocyst width undischarged $(\mu \mathrm{m})$ & * & $3.9 \pm 0.57(10)$ \\
\hline Nematocyst length discharged $(\mu \mathrm{m})$ & * & $18.5 \pm 2,6(4)$ \\
\hline Nematocyst width discharged $(\mu \mathrm{m})$ & * & $4 \pm 0.82(4)$ \\
\hline \multicolumn{3}{|c|}{$\begin{array}{l}1 \text { measured between the two hydrothecae, considering the hydrothecae width; } \\
2 \text { measured internally, between the two hydrothecae, not considering the hydrothecae width; } \\
3 \text { measured at the middle; } \\
\text { * The colony seemed to be dead a long time before the collection and some features were in bac } \\
\text { condition to visualize and measure. }\end{array}$} \\
\hline
\end{tabular}

Ecology: This species is mentioned mainly for the open ocean on mud with some radiolarians and globigerines, coral sand, coarse and fine sand with clay, small stones and shells (Watson, 2000), on organic hard substrates of the outer slope of coral reefs and basaltic cliffs (GravierBonnet, 2008). The colonies described in this paper were found on an artificial substrate, with hydrorhiza partially on Polychaeta tubes. The plates were S. tetracythara was found also had calcareous and membranous Polychaeta tubes, oysters, barnacles, bryozoans, and other hydroid species.

\section{DISCUSSION}

Species of Salacia are distinguished by partly or completely adnate sessile hydrothecae with no distinct marginal teeth, triangular aperture, operculum of one large abcauline valve and hydranth without abcauline caecum (Millard, 1975; Bouillon et al., 2006). The species is also differentiated from Staurotheca for having hydrothecae in two longitudinal rows and from Thuiaria for having retracted hydranth without abcauline caecum (Bouillon et al., 2006). The specimens of S. tetracythara found in the Sergipe River, despite being sterile, match the morphological features of the trophosome and dimensions of the nematocysts reported for the genus and species in classical and recent works (e.g., Bale, 1884; Billard, 1925; Watson, 2000; Gravier-Bonnet, 2008). Although the original and successive descriptions of $S$. tetracythara mentioned that the orifice of the species has some cusps, we found none on the Sergipe colonies. The absence 

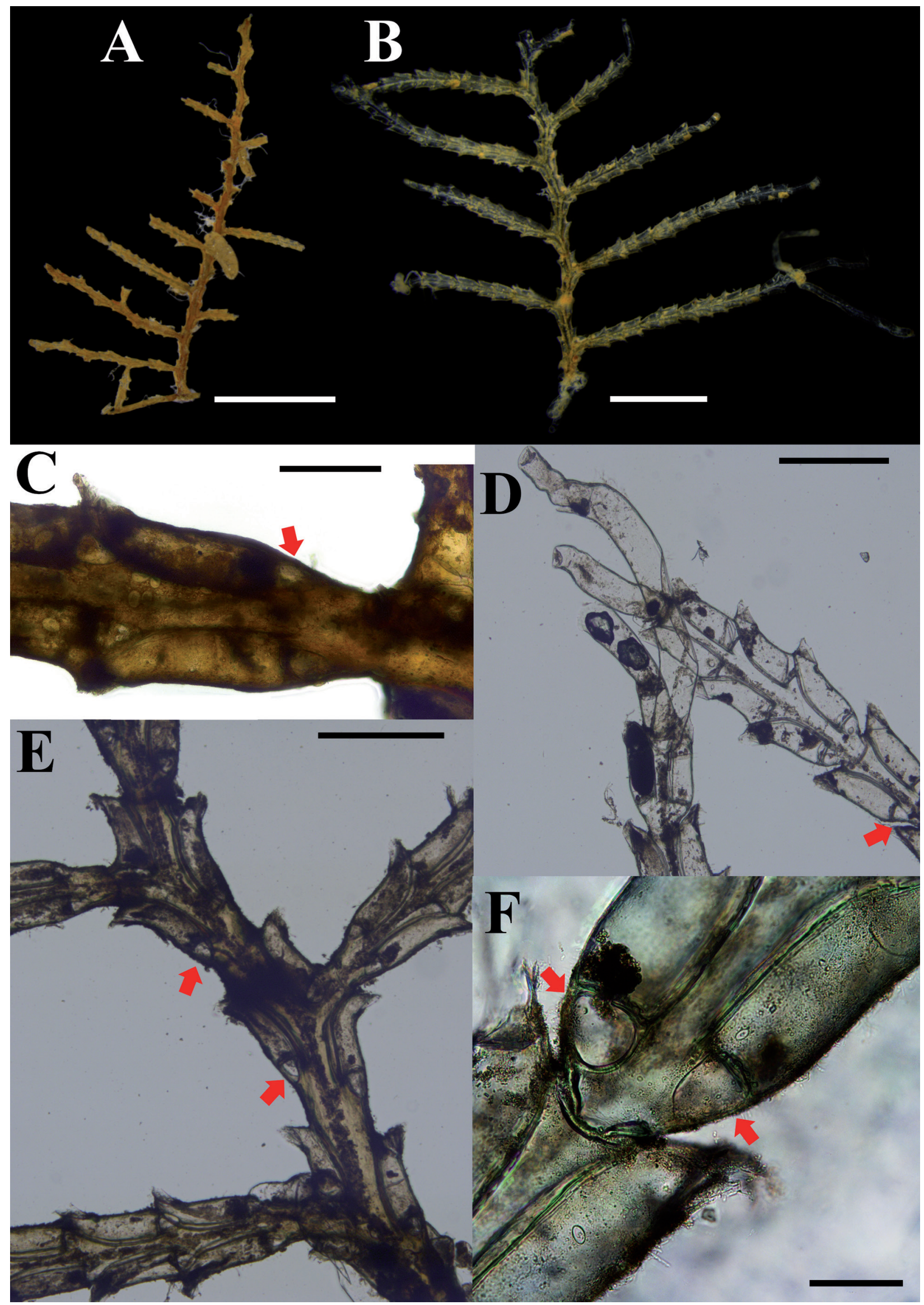

Figure 2. Salacia tetracythara Lamouroux, 1816, two colonies found in estuary of Sergipe River, northeast Brazil: CZUFS CNI-00065 (A) and CZUFS CNI-00066 (B). Details of first pair of hydrothecae from one hydrocladium of first colony (C). Details of second colony: terminal region of two hydrocladia showing tendrils (D); stem and three parts of hydrocladia (E); first pair of hydrothecae from one hydrocladium (F). Red arrows showing thin triangular to ovoid adcauline spaces. Scales: $A=5 \mathrm{~mm} ; B=2 \mathrm{~mm} ; C=200 \mu \mathrm{m} ; D-E=500 \mu \mathrm{m} ; F=100 \mu \mathrm{m}$. 
of cusps was also observed by Gravier-Bonnet (2008). Billard (1925) and Gravier-Bonnet (2008) mentioned that the cusps are not true cusps, but angles made up of skeleton plates of the wall of the hydrothecae at the orifice, which may be more accentuated in some specimens, resembling cusps.

Salacia tetracythara is a distinct species of Salacia and similar species are currently assigned to Thuiaria Fleming, 1828 [e.g., T. articulata (Pallas, 1766) and T. thuja (Linnaeus, 1758)]. The relationship between Salacia and Thuiaria needs to be deeply studied and, future revisions could put together these two genera or appropriately separate them. Watson (2000) mentioned that S. tetracythara superficially resembles S. sinuosa (Bale, 1888), but these two species are easily distinguished by colony form (S. sinuosa has long and strongly fascicled stems and the oval spaces below the hydrotheca are separated from their base) and the shape of the gonothecae, that in the later species has distinct transverse annulations, aperture large, margin elevated, a few long more crook teeth or spines inside the neck.
Salacia tetracythara is a tropical to temperate IndoPacific species (Lamouroux, 1816; Bale, 1884; Billard, 1925; Rees \& Vervoort, 1987; Watson, 2000; GravierBonnet, 2008; Song, 2016) and this is the first record of the species for the Atlantic Ocean. It is also a new record for the genus in the South Atlantic as the third species of Salacia found on the Brazilian coast (see Oliveira et al., 2016). Our sampling point is far from the previous records for this species and there is no natural connection between the Atlantic and Pacific Oceans. Thus, a natural dispersal to the Atlantic Ocean does not seem probable for this species.

This is not only the first detection of this species in the Atlantic Ocean but also the first time that the species was found on artificial substrates and in an estuarine zone. Those information together with the fact of the area where the species was found being close to a port strongly suggests anthropogenic introduction through shipping. Ports and ships are considered the main vectors for the artificial translocation of alien species (Cohen \& Carlton, 1998; Kauano et al., 2017). Some authors have

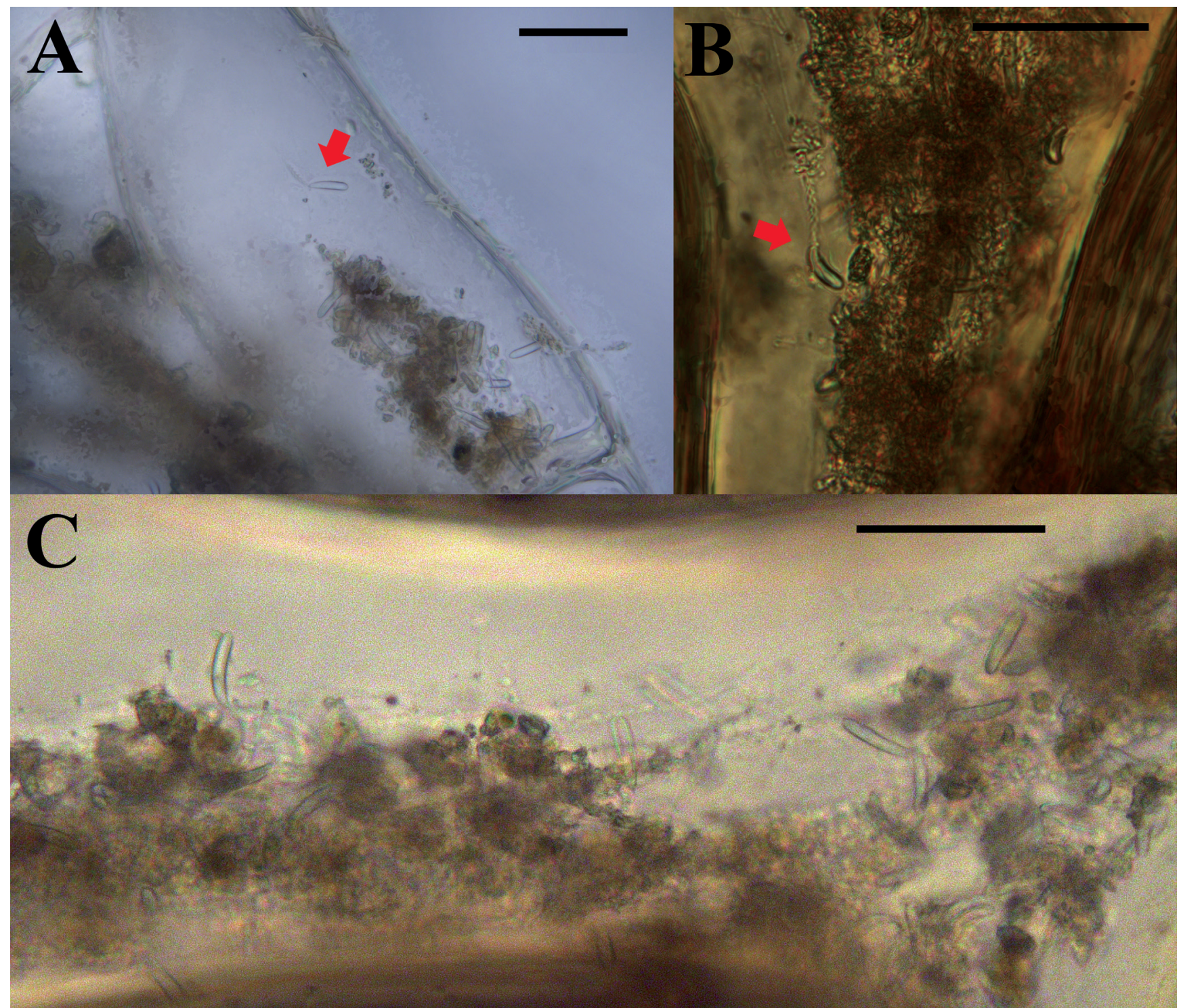

Figure 3. Large microbasic mastigophore nematocysts undischarged and discharged (red arrow) found in polyp body (A, B) and coenosarc between hydrothecae on hydrocladia (C). Scales: $A-C=50 \mu \mathrm{m}$. 
found a high diversity of hydroids on seawalls in commercial harbors (Farrapeira et al., 2011; Marques et al., 2013; Pestana et al., 2017) and marinas (Farrapeira et al., 2011; Megina et al., 2016). Alien species translocated by shipping and established within commercial harbors can later spread to local and regional areas through recreational boats (Neves et al., 2007).

Among the 49 species of cryptogenic hydroids recorded for Brazilian waters, ten are sertulariids, mainly species of Sertularia, which are considered circumtropical or cosmopolitan (Marques et al., 2013; Rocha et al., 2013). This wide distribution does not occur with S. tetracythara, as it seems to be naturally recorded to tropical, subtropical and temperate Indo-Pacific regions, which is another reason to believe that the present case is an introduction into the Atlantic Ocean. Even if the life cycle of S. tetracythara is not known, the family and genera are characterized by fixed sporosacs or by liberating a free-living stage as a strongly reduced medusa (Bouillon et al., 2006). The species is mentioned as colonizing rock shores and coral reefs in open marine regions but also has few records in shallow waters associated with many types of hard substrates (Watson, 2000; Gravier-Bonnet, 2008). There are two main possibilities of introduction for this species: (1) some specimens could colonize the ships hulls and/or incrustate other species (e.g., barnacles, tubiculous polychaetes) and; (2) this species could have a resistance stage and be transported either in the ballast water or on the ship hulls.

Once these organisms survive, the absence of hard substrates on the shallow regions of Sergipe's continental shelf could lead them to a close estuarine region. Is also important to mention that the estuarine region of Sergipe River where S. tetracythara was sampled is a high saline area, sometimes even higher than the sea. Although the species has been recorded only to Pacific and Indian regions, its range area is not as close as it looks and the species is found on many islands and coastal regions including temperate ones, meaning that it is a resistant organism and that could colonize many areas and substrates.

The natural introduction of S. tetracythara into the Atlantic Ocean does not seem probable, given that the species had never previously been detected in the western or eastern basins of the Atlantic (e.g., Allman, 1888; Nutting, 1904; Fraser, 1947; Calder, 1983; Millard, 1975; Cornelius, 1979; Medel \& Vervoort, 2000; Medel Soteras et al., 1991; Migotto et al., 2002; Genzano et al., 2009; Oliveira et al., 2016). S. tetracythara seems to be a recent introduction into the Atlantic Ocean, as the material recorded in this paper was associated with an artificial habitat (pier) in an estuarine zone close to a harbor, which is a hotspot for the introduction of alien species.

It is important to mention that a large study on hydroids of the state of Sergipe has been underway since 2016, including sampling on the continental shelf and other estuarine regions. Therefore, it seems likely that it is a recent introduction, possibly derived from ship transport between the Sergipe harbor and regions of Asia. Further investigation should be conducted to determine whether
S. tetracythara is established in the region and how far inside the estuary it has gone, including molecular analysis to better confirm the alien status for this species.

\section{ACKNOWLEDGEMENTS}

This study was financed in part by the Coordenação de Aperfeiçoamento de Pessoal de Nível Superior - Brazil (CAPES) - Finance Code 001. We also thank the reviewers for their comments and suggestions that helped to make this work better.

\section{AUTHORS' CONTRIBUTIONS}

LMCM, CRPG, and MAH designed the study. LMCM and CRPG performed the field and laboratory studies. LMCM, CRPG, MMGD, and MAH prepared the manuscript. All authors approved the final manuscript.

\section{CONFLICT OF INTEREST}

Authors declare there are no conflicts of interest.

\section{REFERENCES}

Agência Nacional de Transportes Aquaviários (ANTAQ). 2019. Avaiable at: http://web.antaq.gov.br/Anuario. Access: 06/09/2019.

Alcântara, A.V.; Rocha, C.E.F. \& Santos, M.A. 1979. Caracterização hidrológica e biológica do estuário do Rio Sergipe. Sergipe, Unigráfica (UFSE).

Allman, G.J. 1888. Voyage of H.M.S. Challenger. Report on the Hydroida dredged by H.M.S. Challenger during the years 1873-76. Part II - The Tubularinae, Corymorphinae, Campanularinae, Sertularinae and Thalamophora. Report on the Scientific Results of the Voyage of H.M.S. Challenger during the Years 1873-76. Zoology, 23(70): 1-90, pls. I-XL.

Bale, W.M. 1884. Catalogue of the Australian hydroid zoophytes. Sydney, Australian Museum. 198p. pls. 1-19. (Catalogue, 8)

Billard, A. 1925. Les hydroïdes de l'expédition du Siboga. II. Synthecidae et Sertularidae. Leide, E.J. Brill. p. 117-232. (Siboga Expeditie, 7b)

Boero, F. 2002. Ship-driven biological invasions in the Mediterranean Sea. In: Briand, F. (Ed.). Alien marine organisms introduced by ships in the Mediterranean and Black seas. CIESM Workshop Series, 20: 87-91.

Bouillon, J.; Gravili, C.; Pagès, F.; Gili, J. M.; Boero, F. 2006. An Introduction to Hydrozoa. Mémoires du Muséum National d'Histoire Naturelle, 194:1-591.

Calder, D.R. 1983. Hydroida from estuaries of South Carolina, USA: families Sertulariidae and Plumulariidae. Proceedings of the Biological Society of Washington, 96: 7-28.

Cohen, A.N. \& Carlton, J. 1998. Accelerating invasion rate in a highly invaded estuary. Science, Washington, 279(5350): 555-558. D0l

Cornelius, P. 1979. A revision of the species of Sertulariidae (Coelenterata, Hydroida) recorded from Britain and nearby seas. Bulletin British Museum (Natural History), 34(6): 243-321.

Farrapeira, C.M.R.; Tenório, D.O. \& Amaral, F.D. 2011. Vessel biofouling as an inadvertent vector of benthic invertebrates occurring in Brazil. Marine Pollution Bulletin, 62: 832-839. D01

Fraser, C.M. 1947. Hydroids of the 1939 Allan Hancock Caribbean sea expedition. Allan Hancock Atlantic Expedition, 4: 1-24. 
Genzano, G.N.; Giberto, D.; Schejter, L.; Bremec, C. \& Meretta, P. 2009. Hydroid assemblages from the southwestern Atlantic 0cean (34-42 $\left.{ }^{\circ} \mathrm{S}\right)$. Marine Ecology, 30(1): 33-46.

Gibbons, M.J. \& Ryland, J.S. 1989. Intertidal and shallow water hydroids from Fiji. I. Athecata to Sertulariidae. Memoirs of the Queensland Museum, 27(2): 377-432. [Coelenterata: 52-78].

Gili, J.M. \& Hughes, R.G. 1995. The ecology of marine benthic hydroids. Oceanography and Marine Biology An Annual Review, 33: 351-426.

González-Duarte, M.M.; Megina, C. \& Piraino, S. 2014. Looking for long-term changes in hydroid assemblages (Cnidaria, Hydrozoa) in Alboran Sea (South-Western Mediterranean): a proposal of a monitoring point for the global warming. Helgoland Marine Research, 68(4): 511-521.

Gravier-Bonnet, N. 2008. The hydranth of Salacia tetracythara (Cnidaria: Hydrozoa: Sertulariidae) and its modified tentacles. Journal of the Marine Biological Association of the United Kingdom, 88(8): 1723-1729.

Haydar, D. 2012. What is natural? The scale of cryptogenesis in the North Atlantic Ocean. Diversity and Distribution, 18(2): 101-110. DOI

Kauano, R.V.; Roper, J.J. \& Rocha, R.M. 2017. Small boats as vectors of marine invasion: experimental test of velocity and desiccation as limits. Marine Biology, 164: 27. DOI

Lamouroux, J.V.F. 1816. Extrait d'un mèmoire des polypiers coralligénes non entièrement pierreux. Nouveau Bulletin des Sciences par la Société Philomathique de Paris, 3: 181-188.

Leclère, L.; Schuchert, P.; Cruaud, C.; Couloux, A. \& Manuel, M. 2009. Molecular phylogenetics of Thecata (Hydrozoa, Cnidaria) reveals longterm maintenance of life history traits despite high frequency of recent character changes. Systematic Biology, 58(5): 509-526. D0I

Maronna, M.M.; Miranda, T.P.; Peña Cantero, A.L.; Barbeitos, M.S. \& Marques, A.C. 2016. Towards a phylogentic classification of Leptothecata (Cnidaria, Hydrozoa). Scientific Reports, 6: 18075. D0I

Marques, A.C.; Klôh, A.S.; Migotto, A.S.; Cabral, A.C.; Rigo, A.P.R.; Bettim, A.L.; Razzolini, E.L.; Cascon, H.M.; Bardi, J.; Kremer, L.P.; Vieira, L.M.; Bezerra, L.E.A.; Haddad, M.A.; Oliveira Filho, R.R.; Gutierre, S.M.M.; Miranda, T.P.; Franklin-Jr., W. \& Rocha, R.M. 2013. Rapid assessment survey for exotic benthic species in the São Sebastião Channel, Brazil. Latin American Journal of Aquatic Research, 41(2): 265-285. DOI

Medel Soteras, M.; García, F. \& García-Gómez, J. 1991. La familia Sertulariidae (Cnidaria: Hydrozoa) en el estrecho de Gibraltar y la peninsula iberica: Aspectos taxonómicos y zoogeográficos. Cahiers de Biologie Marine, 32(4): 503-543.

Medel, M. \& Vervoort, W. 2000. Atlantic Thyroscyphidae and Sertulariidae (Hydrozoa, Cnidaria) collected during the CANCAP and Mauritania-II expeditions of the National Museum of Natural History, Leiden, The Netherlands. Zoologische Verhandelingen, Leiden, 320: 1-85. (CANCAP Project Contribution n. 120)
Megina, C.; González-Duarte, M.M. \& López-González, P.J. 2016. Benthic assemblages, biodiversity and invasiveness in marinas and commercial harbours: an investigation using a bioindicator group. Biofouling, 32: 465-475. D0I

Migotto, A.E.; Marques, A.C.; Morandini, A.C. \& Silveira, F.L. 2002. Checklist of the Cnidaria Medusozoa of Brazil. Biota Neotropica, 2: 1-31. D0I

Millard, N.A.H. 1975. Monograph on the Hydroida of southern Africa. Annals of the South African Museum, 68: 1-513.

Neves, C.S.; Rocha, R.M.; Pitombo, F.B. \& Roper, J.J. 2007. Use of artificial substrata by introduced and cryptogenic marine species in Paranaguá Bay, southern Brazil. Biofouling, 23: 319-330. DOI

Nutting, C.C. 1904. American hydroids. P. II, the Sertulariidae. Spec. Bulletin of the United States National Museum, 4(2): 1-325.

Oliveira, 0.M.P.; Miranda, T.P.; Araujo, E.M.; Ayón, P.; Cedeño-Posso, C.M.; Cepeda-Mercado, A.A.; Córdova, P.; Cunha, A.F.; Genzano, G.N.; Haddad, M.A.; Mianzan, H.W.; Migotto, A.E.; Miranda, L.S.; Morandini, A.C.; Nagata, R.M.; Nascimento, K.B.; Nogueira-Jr., M.; Palma, S.; Quiñones, J.; Rodriguez, C.S.; Scarabino, F.; Schiariti, A.; Stampar, S.N.; Tronolone, V.B. \& Marques, A.C. 2016. Census of Cnidaria (Medusozoa) and Ctenophora from South American marine waters. Zootaxa, 4194(1): 1-256. D0I

Pestana, L.B.; Dias, G.M. \& Marques, A.C. 2017. A century of introductions by coastal sessile marine invertebrates in Angola, South East Atlantic Ocean. Marine Pollution Bulletin, 125(1-2): 426-432. D0I

Preker, M. \& Lawn, I.D. 2010. Hydroids (Cnidaria: Hydrozoa: Leptolida) from Moreton Bay, Queensland, and adjascent regions: a preliminary survey. Memoirs of the Queensland Museum - Nature, 54(3): 109-149. (Proceedings of the Thirteenth International Marine Biological Workshop, The Marine Fauna and Flora of Moreton Bay, Queensland).

Rees, W.J. \& Vervoort, W. 1987. Hydroids from the John Murray Expedition to the Indian Ocean with revisory notes on Hydrodendron Abietinella, Cryptolaria and Zygophylax (Cnidaria: Hydrozoa). Zoologische Verhandelingen, Leiden, 237: 1-209.

Rocha, R.M.; Vieira, L.M.; Migotto, A.E.; Amaral, A.C.Z.; Ventura, C.R.R.; Pitombo, F.B.; Santos, K.C.; Lopes, R.M.; Pinheiro, U. \& Marques, A.C. 2013. The need for more rigorous assessments of marine species introductions: a counter example from the Brazilian coast. MarinePollution Bulletin, 67:241-243. D01

Schuchert, P. 2003. Hydroids (Cnidaria, Hydrozoa) of the Danish Expedition to the Kei Islands. Steenstrupia, 27(2): 137-256.

Song, X. 2016. Diversity and evolution of Sertulariidae Lamouroux 1812 (Cnidaria: Hydrozoa) in China with records from Chinese National Arctic and Antarctic Research Expeditions. PhD Dissertation, University of Chinese Academy of Sciences.

Watson, J.E. 2000. Hydroids (Hydrozoa: Leptothecatae) from the Beagle Gulf and Darwin Harbour northern Australia. The Beagle: Records of the Museums and Art Galleries of the Northern Territory, 16: 1-82. 